\title{
\{3 PRIO
}

\section{I ndependent • International • | nterdisciplinary PRIO PAPER \\ Understanding Warlordism}

Three Biographies from A fghanistan's Southeastern A reas

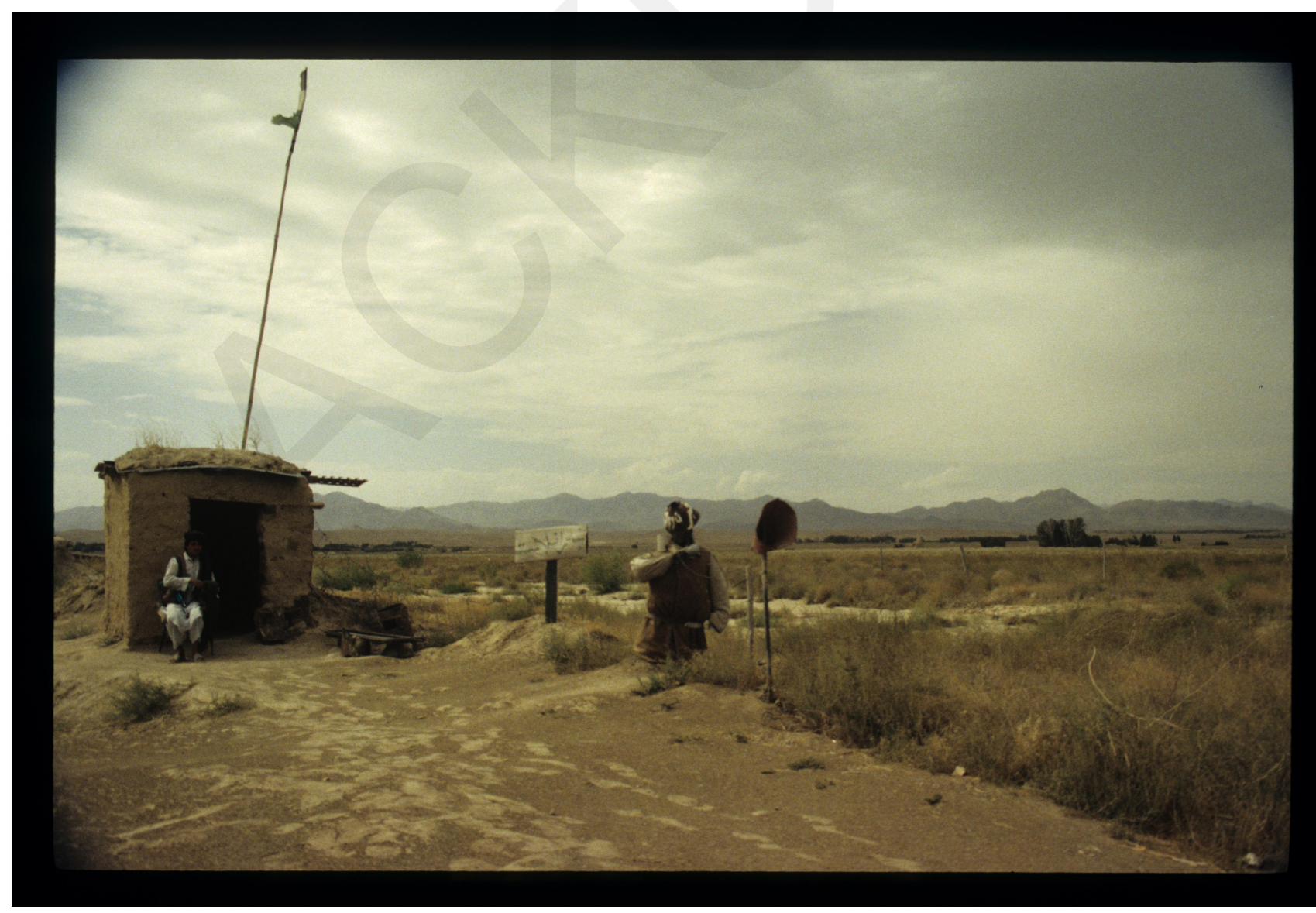

Kristian Berg Harpviken

Peace Research Institute Oslo (PRIO) 


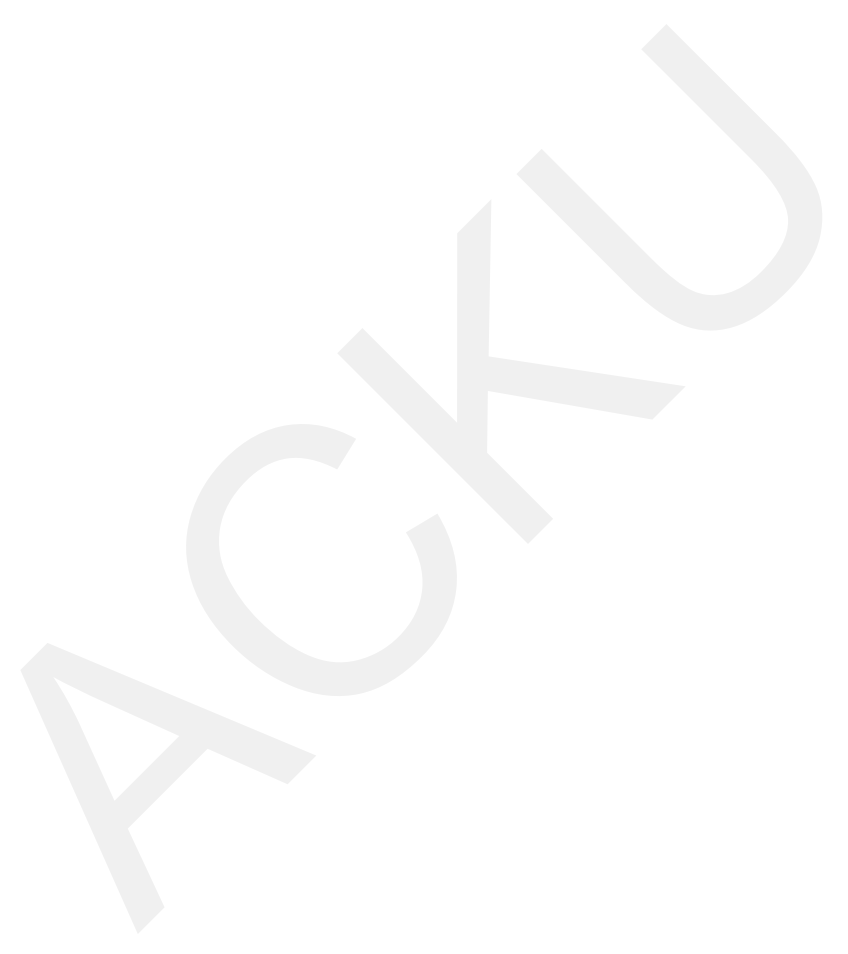




\section{Understanding Warlordism: \\ Three Biographies from Afghanistan's Southeastern Areas}

Kristian Berg Harpviken 
This PRIO Paper is written within the framework of the project 'Violence in the Post-Conflict State', jointly led by Astri Suhrke (Chr. Michelsen Institute) and Mats Berdal (King's College London), and funded by the the Research Council of Norway. The paper was completed in January 2010, and does not reflect later developments.

About the author: Kristian Berg Harpviken has a PhD in Sociology from the University of Oslo (2006) and is currently director of the Peace Research Institute Oslo (PRIO). His research interests include the dynamics of civil war (mobilisation, conflict resolution, post-war reconstruction and peacebuilding); migration and transnational communities; and methodology in difficult contexts. He has a particular interest in Afghanistan and the region.

(C) Peace Research Institute Oslo (PRIO), 2010.

All rights reserved. No part of this publication may be reproduced, stored in a retrieval system or utilized in any form or by any means, electronic, mechanical, photocopying, recording, or otherwise, without permission in writing from the copyright holder.

ISBN: 978-82-7288-366-8 


\section{Understanding Warlordism: Three Biographies from Afghanistan's Southeastern Areas ${ }^{1}$}

How do 'warlords' - defined in the Afghan context both by their military skills and capacity to strike a balance between local and external sources of support - respond when the war they are fighting ends? Why do some choose compliance with the new political order while others remain engaged in various forms of opposition? The political biographies of three longstanding warlords of the largely Pashtun southeast of Afghanistan - Mullah Rocketi, Qari Baba, and Jalaluddin Haqqani - enable us to explore the dynamics of quite different responses. The 2001 US-led intervention and the transitional challenges that followed led the three men in different directions. Rocketi took up a political career, was elected to parliament in 2005, and four years later remained an active player in legal politics. Qari Baba served briefly as a governor but was dethroned to the position of a security advisor and then assassinated (probably by local Taliban). Haqqani stayed with the Taliban to become one of its most central commanders and by late 2009 led one of the major militant groups in the insurgency. All three had emerged as commanders during the anti-Soviet jihad of the 1980s. Notwithstanding the considerable social and political similarities in the context where they operated and the challenges they faced, their personal trajectories diverged in the post-2001 period. This paper will try to understand why this was so: Why did one man lay down his arms to become a politician, another place his capacity for commanding violence at the service of the new Karzai government, while the third continued to challenge the new rulers with armed force? The analysis of these trajectories will provide an insight into the nature of violent warlordism during the formal transition from war to peace and into the postconflict period.

\section{The Historical Context for the Emergence of Afghan Warlords}

The 1978 coup by the People's Democratic Party of Afghanistan (PDPA), followed by the late 1979 Soviet intervention, led to the emergence of a large set of resistance commanders in Afghanistan. Initially, the resistance was largely in the form of local defense against the coercive reforms of the PDPA (Shahrani 1984). Such community militias were embedded in the local community and were sometimes led by traditional notables, including Islamic scholars. By the beginning of the 1980s, however, political parties based in Pakistan and Iran were established. These parties had somewhat distinct

\footnotetext{
${ }^{1}$ In researching this paper I owe a great debt to two Afghan research assistants, who due to the sensitivity of the topic must remain anonymous. I am also grateful for comments on earlier versions from Arne Strand and Astri Suhrke. Finally, I am deeply grateful to all those Afghans who have volunteered their time to be interviewed for this study, but whose identities I have committed not to reveal.
} 
ideological profiles and became important as conduits for military, financial and humanitarian assistance from abroad. The top echelons of the party were either Islamic scholars, students or alumni from the rapidly growing universities, which were home to a range of new - often radical - political groups (Edwards 1986; Roy 1986).

Most of the so-called parties were loosely organized and had limited control over their field commanders, many of whom came from community militias where they had made their mark as effective military leaders (Bhatia and Sedra 2008: Ch. 3; Giustozzi 2007). I will here refer to such local and regional leaders as warlords, without giving the term derogatory meaning. Warlords are individuals who built personal power in the context of war, deriving their main legitimacy from their capacity for organized violence, as Giustozzi has noted (Giustozzi 2003). While anchoring their organizations in local networks and identity groups, the Afghan warlords were increasingly able to circumvent the checks and balances inherent in traditional structures. Although dependent on external support (from exile-based parties, foreign governments and aid agencies), the warlords also had to strike alliances with the very government that it was fighting, and negotiate support from local powerholders and supporters.

The warlords - then commonly referred to as commanders - remained the central actors in the armed resistance of the jihad until the PDPA government disintegrated in 1992 and a coalition of resistance groups seized power. During the reign of the so-called mujahedin government (1992-1996), many of the former commanders held key positions. ${ }^{2}$ By 1996, the Taliban took Kabul, having swept across most of the southern half of the country. Former commanders were dethroned; some were incorporated into the Taliban, while others left for exile or for the mujahedin-controlled areas in the northeast.

When the US-led intervention started on 7 October 2001, most of the old warlords who were not with the Taliban had for some time been enrolled under the anti-Taliban banner of what was called the Northern Alliance and equipped with money, weaponry and communications gear. The ground fighting in 2001 - complementing US aerial bombardment of Taliban positions - was conducted almost exclusively by Afghans (Woodward 2002; Rashid 2008: Ch. 4). Later, the commanders who took part were generously rewarded for their services by president Karzai, who - encouraged by his US allies - based his rule in part on accommodating former warlords (Giustozzi 2004). This proved to be a problematic strategy, however. Key positions were filled with people who had every reason to worry that in a peaceful Afghanistan they would lose their jobs and be made responsible for war crimes (Abdullaev 2004; Rubin 2003). The program for

\footnotetext{
${ }^{2}$ Formally, the mujahedin government, led by Burhanuddin Rabbani, remained the country's internationally recognized government until replaced by Karzai's interim administration in late 2001.
} 
disarmament, demobilization and reintegration (DDR) was only moderately successful (Bhatia and Sedra 2008: Ch. 4; Strand 2008). Only in very few instances were former warlords disempowered by being moved to other positions in the government system. Already a few years into the first term of Karzai's presidency (2004-09), the strong position still held by the warlords was increasingly seen as a threat to stabilization and state-building in Afghanistan, and for good reasons. Their loyalty to the regime is conditional. Many have retained an armed capacity, they continue to abuse local populations, maintain their (not always legal) economic foundations, and some fight each other. Hence, warlords not only constitute a threat to government and international armed forces, but potentially also to any longer term ambition of fostering peace.

\section{Understanding Warlords}

Drawing on the use of the term within history and the social sciences, Antonio Giustozzi (2003) has suggested an elaborate typology of warlords. The main quality of a warlord here is the ability to marshal the means of coercion: the control of military force, the use of force to control some territory, the successful conduct of military operations; and, ultimately, legitimacy as an effective military leader. The political position of a warlord is first and foremost rooted in the ability to apply organized violence (including the threat thereof), as a result of which his or her political legitimacy is limited. The main objective for a warlord is to maintain or expand the power base. In Giustozzi's conceptualization, the mobilization of economic resources is first and foremost a means for maintaining military power. Political ideologies play a negligible role, and the warlord's relations to the local support base are neo-patrimonialist. Other analysts note that warlordism most commonly accompanies state collapse (Reno 1998). It may be a result of a fragmentation of either the state (when elements in its military apparatus evolve into warlords) or of hierarchical non-state armed entities. In Afghanistan, state collapse is the main precursor for warlordism, but within the main trajectory, there are numerous examples of warlords born out of the fragmentation of a state or an armed entity (Bhatia and Sedra 2008: 7888).

The literature suggests three dominant explanations for the emergence of warlords: political economy; ideological; and relational. These are not mutually exclusive; indeed, all three are included in Giustozzi's definition. For the first mode of explanation - the political economy approach - Mancur Olson has been influential. Olson (1993) asserted that once a warlord gains control over a certain area, it is in his interest to provide minimal security to the subjects within. This is a necessary precondition for further economic accumulation. When warlordism develops into a relatively stable system of governance, warlords who fail to provide any public goods - 'roving bandits' - lose out in the competition with those who produce a minimum level of welfare. This explains why 
some warlords may engage in the building of a 'proto-state', providing some degree of welfare and security for the local population to become 'stationary bandits', and indicates why, in a period of transition, some warlords successfully adapt while others fail. Whether the proto-state is built out from narrow economic self-interest or signifies a broader type of social contract (as in a relational account of political economy), is open to interpretation.

Another major political economy advocate is William Reno (1998; 2002). In his work on Africa, warlordism emerges in response to the fragmentation of state authority, with the result that both economic activity and politics are localized. Reno views warlords primarily as self-interested actors aiming to strengthen their own economic and political position. Hence, they are careful not to build up immobile assets that require permanent protection. Reno also modifies Olson's claim about welfare provision: his warlords seek to provide selective incentives to attract the loyalty of a select few rather than providing public goods for the local population at large. Others have gone further, arguing that warlords are primarily motivated by economic greed (Keen 1998; Collier and Hoeffler 2002). Mats Berdal (2003), amongst others, has argued that focusing on greed entails a confusion of means and ends; although warlords need an economic base to maintain their capacity for violence, their rationale is first and foremost to build military-cumpolitical power (see also: Giustozzi 2005: 6-8). It is commonly assumed that reliance upon external suppliers (and supporters) is a warlord's weakest point (Sinno 2008: 14). As Tim Earle (1997) has shown, unless the leader in question has a steady supply of highly valued goods from external sources, disaster may strike. Insights from general network theory would suggest, however, that a valued agent (the warlord) who has built support ties to multiple external backers may enjoy considerable independence derived from the ability to play the one against the other. ${ }^{3}$

What about ideology? Few, if any, would argue that ideology explains the behavior of warlords. Rather, there is a virtual consensus that warlords are pragmatic actors. Their very ability to maneuver pragmatically - although often in political landscapes that are ideologically charged - is a key to their success. Warlords are described as self-interested actors with little interest in ideology (Reno 1998). Accordingly, they have little interest in changing the nature of the state (Giustozzi 2005). Furthermore, Weinstein (2007) claims that there is a trade-off between resources and ideology: political groups with generous resource endowments recruit opportunists. In contrast, groups with few resources have to play on ideology. Nonetheless, ideology seems to come into play in several ways. Firstly, warlords may rely on some sort of preexisting legitimacy to achieve power. In the case of Afghanistan, a vast majority of warlords, including the three discussed in this paper, held religious positions and legitimized their role in Islamic terms (Giustozzi

\footnotetext{
${ }^{3}$ For more on network approaches to the study of armed conflict, see Wood (2008).
} 
2007). Secondly, warlords may abstain from challenging the everyday ideologies inherent in shared norms, acting in accordance with established constraints on the use of violence (Wood 2008: 550). ${ }^{4}$ Thirdly, warlords, and their constituencies, are exposed to ideology through their relationships with external backers, whether political parties, transnational movements or foreign governments. As the synergetic relationships between local warlords and their external backers deepen, mid-level leaders and new recruits may become more exposed to ideological training. Lastly, warlords of ambition may seek to become regional powerholders (what Giustozzi describes as "strongmen"), or even politicians of national stature, and in the process stake out a rudimentary ideology. ${ }^{5}$ Ultimately, the reference to military proficiency - often talked about as 'military charisma' - also entails an element of ideology in that it gives primary importance to the need for self-defense, for local security.

The third approach to understanding warlords is relational (Tilly 2003; Wood 2008). Although some local armed movements have been described as business organizations of a virtual mercenary character, most analysts agree that warlords rely on preexisting social bonds. Ties via family, tribe, ethnicity, religion, or shared locality are important both for recruitment and support. In the recent debate on the nature of stateless post1993 Somaliland (e.g. Menkhaus 1998), a prominent argument is that due to their reliance on solidarity ties, warlords are also accountable to their local constituents (e.g. Marten 2007). In this understanding, warlordism can be a fairly stable political system, and it can be partially responsive to the local populations' need for security and welfare. Others, however, see a sequence in which emerging warlords rely on local support, but over time build considerable independence. Drawing on the Afghan case, Michael Bhatia found that a commander may initially be selected by a local representative body (a shura), but may over time become the one to decide on the composition of the same body, thus effectively removing any checks and balances (Bhatia and Sedra 2008: 86). Influence, however, need not go only one way. Warlords intent on making the transition into regional strongmen or politicians may find it necessary to strengthen the relationships with their constituencies. As Antonio Giustozzi (2007) sees it, the challenge may be that success as a warlord and a violent reputation is two sides of the same coin. It may be more promising to resort to 'armed politics', using coercion both to enforce compliance and offer protection to supporters. In the absence of an alternative representation that gains the confidence of locals, this explains why warlordism can be a fairly stable political system that is not easily dismantled (Marten 2007).

\footnotetext{
${ }^{4}$ For interesting discussions of the contrast between the constraints of the traditional tribal feud and the unconstrained conduct of modern warfare in the Pashtun areas of Afghanistan, see: Bhatia and Sedra (2008: Ch. 3); Giustozzi (2007).

${ }^{5}$ In the latter case, they may seek to develop a more coherent political program, often rooted in ethnic or regional identities
} 
With these three explanatory dynamics in mind, let us explore the trajectories of our three Afghan warlords.

\section{Three Afghans}

The three Afghans - Mullah Rocketi, Qari Baba, and Jalaluddin Haqqani - are chosen here for several reasons. First, all emerged as military commanders in the resistance against the PDPA and the Soviets in the 1980. They are all from the Pashtun heartlands in the southeastern ${ }^{6}$ part of the country, an area where tribal solidarity have proven remarkably resilient in the encounter with war. While this was the home area for many members of the PDPA, it was also core area for the resistance parties, particularly those of a traditionalist Islamic orientation. In 1994, the Taliban emerged, first further south, around Uruzgan and Kandahar, and quickly spread eastwards throughout the Pashtun belt. They met minimal armed resistance. Local commanders were faced with the choice between resisting or going underground, fleeing, or subordinating themselves to the Taliban. Joining meant in worst case that Taliban would deprive them of their armed forces, and at best appoint them in official posts.

Second, the three followed different strategies for adapting to the post-Taliban situation. Third, the background of all three is sufficiently well known so that the present analysis does not violate privacy concerns. ${ }^{7}$ The paper is primarily based on interviews with key informants who have first-hand knowledge of the three men. ${ }^{8}$ The interviews have been supplemented by written sources, both in the form of academic analysis and journalistic accounts. Finally, I have followed the political landscapes in which these individuals have operated through almost two decades, and I have personally met several times with Jalaluddin Haqqani and Qari Baba.

\section{Mullah Rocketi: Tribal-Traditional Warlord}

Mullah Rocketi was elected to the parliament in 2005, representing Zabul province, where he had been the major commander for most of two decades. The nickname, 'Rocketi', signifies his reputation as quite a marksman with the Rocket Propelled

\footnotetext{
${ }^{6}$ In formal terms, Zabul province (Rocketi's domain) is not Southeast Afghanistan, but belongs to the Southern region.

${ }^{7}$ All three have themselves been relatively open about their backgrounds and their choices. Qari Baba was assassinated in 2006. Jalaluddin Haqqani remains actively engaged with the Taliban, and is currently off hands for journalists and academics, but has been rather accessible in the past. Mullah Rocketi, a member of parliament since late 2005, gives regular interviews reflecting on his past.

${ }^{8} \mathrm{~A}$ total of 30 interviews have been conducted specifically for this project (11 focusing on Rocketi, 10 on Baba, six on Haqqani, and three interviews dealing with all of them)
} 
Grenade (RPG) launcher. His real name is Mullah Abdul Salam. ${ }^{9}$ Rocketi was a commander of Sayyaf's Ittehad-e Islami, an Islamist group with a Wahabi orientation - a rigorous school of thought originating in what is today Saudi Arabia - despite feeling more at home with traditionalist Afghan groups. Never an active builder of local welfare, Rocketi emphasized local security and always displayed a strong sense for pragmatic deals. Representing classic Pashtun values, Rocketi was never attracted by new types of religio-political ideology. He represents the type of commander that is rooted in local networks and values, acting as a middleman with strong political currents that originate externally. As such, Rocketi may be the one, amongst the three discussed here, that comes the closest to an ideal-type warlord as defined at the outset of this chapter. Ironically, he is also the one who - although not without pains of transition - has become an integral part of the post-2001 power structure.

Mullah Abdul Salam was born in Sinak village, close to Qalat, the provincial capital of Zabul, somewhere around $1957 .{ }^{10} \mathrm{He}$ is married and has eight children (five sons; three daughters), the eldest son is now (2009) nineteen years old. Mullah Rocketi has basic madrasa training, but is not fully literate. He led a local madrasa in Zabul prior to the war, but was still in his early twenties at the time of the Soviet intervention in late 1979, after which he joined the resistance. In the words of one informant: 'he has a divine gift for military strategy'. Quickly gaining a reputation as an effective military commander, Mullah Rocketi also played on his background within the Suleiman Khel lineage of Pashtuns, and tribal solidarity was probably more important than religious legitimization for his support.

Having taken up arms in response to the Soviet intervention, Mullah Rocketi emerged as one of the major commanders of Ittehad-e Islami. His relationship with the party leader, Abdul Rasool Sayyaf, became increasingly conflictual, both as a result of ideological differences, and because Rocketi was skeptical to the strong Pakistani influence in Sayyaf's movement. His political orientation brought him closer to Maulawi Nabi's Harakat-e Islami, with its traditionalist religious leaning, and in the late 1980s, he shifted his party affiliation, much to Sayyaf's chagrin. Throughout the late 80 s and early 90 s, Rocketi's position as Zabul's main commander was never seriously contested. While there were other commanders affiliated with other parties, they made sure to coordinate and keep in line with Rocketi. In the latter half of the 1980s, the Mullah was, in most people's eyes, functioning as the resistance governor in a province where the PDPA government - apart from the provincial capital Qalat and along the Kabul-Kandahar highway - had minimal say.

\footnotetext{
${ }^{9}$ Occasionally also referred to as Salam Khan.

${ }^{10}$ It is not uncommon in Afghanistan that people lack precise information about the time of their birth.
} 
Rocketi's main support was through the tribal networks, and it was also here that he recruited his combat personnel. The Suleiman Khel tribe does not dominate the tribal landscape in Zabul, and based on his military proficiency, Rocketi gained support also from others tribes, including the Kharoti, Taraki and Tokhi. Through the Suleiman Khel network, he gained influence also outside Zabul, in Ghazni, Helmand, Kandahar, Logar and in Paktika. While a famously effective fighter, Rocketi never had a sizeable professional salaried army, nor - as many other warlords - even a semi-professional one rewarded by booty. Rocketi's pattern of mobilization was of the traditional sort; he was accepted as the most adept commander and mobilized through tribal networks within a relatively confined geographical area. As the main commander in the province, he certainly had generous external sources. This enabled him to reward those loyal to him and convince others that they should join in. He never attempted, however, to build an economic base of his own. Neither did he have multiple sources of external sources of support. For this reason, he was vulnerable to shifts in the larger political landscape.

Despite his harsh criticism of the Pakistani influence on Afghan politics in general and on the 1980s resistance parties in particular, Rocketi also relied on Pakistan to provide money and arms. Like Qari Baba, he never established himself in Pakistani exile, but he maintained a liaison function and visited the neighboring country regularly. His capacity to fight was as dependent on Pakistani sanctuary as were most of the other groups in the south and east. Yet his contact with the Pakistanis, made him more hostile to their interference. The killing of his brother in the early 1980s, allegedly by Pakistani intelligence services, stayed with him. In mid-1994, one of his bases was allegedly searched by Pakistani forces looking for heat-seeking Stinger missiles in his possession. ${ }^{11}$ Rocketi hit back by taking two Pakistani and seven Chinese hostage, and he demanded payment for his Stingers and the release of his brother from a Pakistani jail (US Department of State 1995). After several months, the hostages were released, reportedly having been maltreated and tortured while in custody. ${ }^{12}$

At the very end of 1994, the Taliban movement, only a few months old, closed in on Zabul. The takeover was virtually bloodless, not a single shot was fired (Rashid 2000: 33). Mullah Omar, the head of the Taliban, knew Rocketi. He was impressed by Rocketi's reputation, and positively inclined as a result of their joint background in Harakat-e Enqelab, a traditionalist party rooted in clerical networks set up in the early days of the jihad. Mullah Rocketi saw Taliban rule was coming, and was weighing for or against: should he resort to passivity, or should he offer his services to the new regime? He decided on the latter and established contact with the Taliban leader already prior to the

\footnotetext{
11 The US Central Intelligence Agency (CIA) was paying handsomely for this at the time, in an effort to prevent them from being available for international terrorists.

12 One claim was that 'Mullah Rocketi's forces hung some foreign captives (...) upside down and beat them to force them to write letter urging that ransom be paid' (US Department of State 1995, Section 1b)
} 
takeover of Zabul. He served as a go-between with Ahmad Shah Massoud, the main commander of the Northern Alliance. Omar had hoped to get Massoud aboard with the Taliban, but failed. ${ }^{13}$ In a 2006 interview, Rocketi says: 'When the Taliban came along, I gave everything to them because I wanted the country to improve and the people to be safe' (Sands 2006). Following years of civil war between a range of different warlords across Afghanistan's south, the Taliban had successfully used religion to transcend existing divisions (mainly within the rural Pashtun population) and establish basic security (based on the harshest means) in areas under its control (Harpviken 1997).

Apart from his role as a messenger to Massoud, Rocketi did not immediately get a position with the Taliban. After a few months, however, he was offered the job as a commander of the $1^{\text {st }}$ army corps in Jalalabad, a post he retained until the fall of the Taliban regime in late 2001. In this post, he engaged in operations in the North, which had an enduring negative impact on his relationship with Northern Alliance leaders many of whom moved to positions of power after 2001. Abdul Salam's attachment to the Taliban is unsurprising; most Pashtun commanders with a similar religious background and political orientation did the same. Nonetheless, the level of trust that the Taliban gave Rocketi is special, first as an envoy to Massoud in 1994-95, and later as a key corps commander until the 2001 fall from power. Few warlords with his level of previous stature gained such confidence from the new rulers.

At the time of the 2001 intervention, Rocketi left his commander post, and sought sanctuary at the shrine of the Gilani family in Jalalabad, a confirmation of his long term links with this influential sufi family network. After a while, he went to Zabul. In late December, he received Ismael Gilani, who now had a mandate from President Karzai, and the two agreed that Rocketi would hand in his weapons, including a handful of Stinger missiles (Kibel 2001). After this, Rocketi went to Kandahar. There, he got protection from Gul Agha Shirzai, the first post-Taliban governor. He was also granted what was understood to be an amnesty from Karzai (Yusufzai 2002). ${ }^{14}$ In May 2002, however, US forces arrested him and took him to Bagram, the main US base north of Kabul. He was held for interrogations for eight months. He was released at the initiative of Karzai, but the main interlocutors were again from the circle around Pir Ahmad Gilani, a political and spiritual leader who was close to Karzai. Upon Rocketi's release,

\footnotetext{
${ }^{13}$ At this point in time, the Taliban still saw itself as a transitional arrangement, aiming to reestablish law and order and hand over power to a new government, perhaps also reinstall the king. Over the next few years, the Taliban leadership developed the ambition to sustain a lasting 'Islamic' regime in Afghanistan (Harpviken 1997).

${ }^{14}$ This was in the first days of the Karzai-led interim administration, and the legal status of this amnesty is not clear. A number of key Taliban leaders were granted amnesty at the time, many had tribal or other affiliation with Karzai himself. The American 'were angry', as 'they would have liked to interrogate them' (Yusufzai 2002)
} 
Gilani's men suggested an appointment as governor of Zabul, but the President was skeptical, probably reflecting US pressure.

Rocketi, however, proved very loyal to the new regime. He took a particularly active stand in the DDR process, first handing in his own weapons and then working with the government to convince other Zabul commanders to do the same and settle DDR-related disputes. In the run-up to the 2004 presidential elections, Rocketi campaigned for Karzai in Zabul and in the 2005 parliamentary elections he was himself a candidate. He campaigned extensively in the province, apparently with generous access to money that could buy support. ${ }^{15} \mathrm{He}$ won a seat in parliament, and settled in Kabul with his wife and children. At the same time, the Taliban was gaining strength in Zabul, which was strategically important, both to the Americans (for rebuilding the Kabul-Kandahar highway) and their adversaries (as a main entry point from Pakistan). Already by late 2003, some $80 \%$ of Zabul was under Taliban control (Rashid 2008: 247). Those perceived to be defectors were targeted by the Taliban, and personal security was becoming a serious concern for people like Rocketi. Nonetheless, Rocketi continued to respond to calls for intervening in local conflicts, and occasionally travelled to his home province for this purpose. In this, he collaborated closely with the US forces operating in the province. When 21 South Koreans were held hostage in Ghazni in 2007, Rocketi was part of a delegation sent to negotiate with the Taliban captors. In June 2008, when endorsing the principle of reconciliation with Taliban, British Foreign Minister David Miliband held up Rocketi as a prime example of success. ${ }^{16}$

In parliament, Rocketi surprised many by distancing himself from his Taliban past and by speaking up against warlords, even to the extent of expressing support for Malalai Joya, the parliament's most vocal warlord critic. Like many others, however, he grew increasingly frustrated by the limited influence of the parliament. When a number of former warlords and politicians who agreed on little but a common dislike for Karzai launched the United National Front in early 2007, Rocketi was on the periphery. Yet he has become increasingly critical of the government:

\footnotetext{
'Then when the current government came along, I gave everything to them because I thought they would make the county better. But I regret that. Everything is gone now, we have nothing. I regret it not because I am no longer with the Taliban, but because our government does not have the power to improve our country.' (Sands 2006).
}

\footnotetext{
${ }^{15}$ In the 2005 parliamentary elections, Zabul had the lowest voter turnout of all provinces in the country, with $20,2 \%$ of registered voters (Wilder 2005: 33 )

16 'Real progress depends on national unity around a clear plan. Today in the Afghan parliament, Mullah Rocketi, formerly a Taliban commander, sits in the same debating chamber as military commanders from the communist era. They have rejected violence in favor of politics. We need to convince others to do the same and that is why I welcome President Karzai's Taliban reconciliation programme.' (Miliband 2008)
} 
Rocketi has continued to distance himself from the Taliban, but distinguishes between their original aims (security, Islamic state) and their means (repression, violence, terrorism). He expresses qualified sympathy for the former (Sennott 2007: 9). Perhaps more importantly, there is little sign that his gifts in the military domain are paralleled in the political sphere, and his influence in parliament is limited. At best, he serves a symbolic purpose as a (at least seemingly) converted warlord, with many colleagues finding him surprisingly friendly, while human rights activists use him to exemplify the failure to take former 'warlords' to court for human rights violations.

In the immediate wake of the 2001 intervention, Rocketi stands out for his willingness to fully dismantle his capacity to exert violence. This did not instill full confidence among all, and US forces jailed him for eight months. In the longer term, however, Rocketi's strategy worked. Few Taliban commanders of his stature were brought in to the political arena the way he was. At the same time, Rocketi had limited choice. Despite considerable tribal and local support, he lacked steady financial sources. He was already uncomfortable with the increasing political radicalization of the Taliban. Furthermore, some of his long-term protectors strongly pressured him to side with the Karzai government. It is interesting to note that post-2001, Rocketi does not associate himself with any standing armed force. Despite the obvious threats to his life, he does not even entertain bodyguards. He does his best to counter his reputation for brutality. At the same time, informers who know the Zabul scene well are in no doubt that he could easily remobilize support if the situation changes. Nonetheless, Rocketi is one of few warlords of stature that has joined the political process, while also effectively laying down his arms.

\section{Qari Baba: Tribal Compromise, Builder of Proto-State}

Qari Taj Mohammad, more commonly known as Qari Baba, was killed in 2006, allegedly by local Taliban sympathizers. He emerged in the early 1980s to become the most prominent commander in the area surrounding Ghazni city, located on the main KabulKandahar road and a strategically important city for the PDPA. His main support base was in Andar district outside Ghazni. A local Islamic scholar in charge of his own madrasa before the war, Qari Baba was an archetypical commander of Harakat-e Enqilab, an Islamic traditionalist party with broad support among the clergy. He was reputed to be firm on his enemies - the 'dictator' being one of his many nicknames - and he certainly played on this violent reputation to instill fear and respect. At the same time, however, Qari Baba aimed at building a proto-state, encouraging local business, promoting health and education services, and collecting local taxes. 
Qari Baba was born in Attal village of Andar district in Ghazni. At the time of his death, he was somewhere in his mid-seventies. He was from a religious family, his father Mawlawi Abdul Wakil being an alim, a trained Islamic scholar. ${ }^{17}$ Qari Baba himself pursued Islamic education at the well-known Noorul madrasa in Ghazni, but did not make it to an advanced level, and never called himself an alim. He was reputed both for his handwriting and his prose. For quite a while he worked as a scribe, stationed in front of the Ghazni governor's office, where he wrote petitions and letters to the governor (two decades later, he would himself fill the governor's chair). Around 1973, he set up a small madrasa in Andar district. Qari Baba fathered one son and four daughters, one of whom married one of his main commanders, Khail Mohammad Hussein (a member of the 2005 parliament)

Qari Baba was of Tajik ethnic origin, which is fairly common in Ghazni city and the surrounding areas. ${ }^{18} \mathrm{He}$ was a fluent Pashtu-speaker, and was generally seen as a commander of Pashtuns. Tribal structures persist in Andar where he had his main power base, and Qari Baba was a compromise candidate between four local Pashtun tribes that were unable in the early 1980 s to agree upon a candidate from their own ranks. Undoubtedly, Qari Baba's political talents as well as his religious background served in his favor. As a compromise candidate, not himself stemming from any of the main local tribes, Baba's case was atypical. It protected him from accusations of only looking after his own interests. An interesting system was set up, apparently lasting at least until the Taliban take-over in 1995, whereby each of the four tribes appointed second-level commanders. This system of tribal sub-commanders served to hold Baba accountable to his local support base, and as a compromise candidate, with no primary constituency, Baba was vulnerable. In the Ghazni area, the general pattern was for resistance leaders to come from a religious background, almost entirely replacing the traditional notables who constituted the main elites prior to the war (Roy 1986: 114). Baba is himself reputed for having purged more than one khan from Andar in the early days of the war. In the words of one informant: 'he had more enemies than I can possibly list'.

Ghazni was one of the few places where there were organized, large-scale revolts against the PDPA government before the Soviet intervention. The networks of religious leaders constituted the core of these early revolts, the first one reported in September 1979.

Mohammad Nabi, who became the leader of one of the main Sunni parties, Harakat-e Enqilab, had taught at the Ghazni madrasa and was widely respected among the local ulama. As Olivier Roy points out, 'the ulama saw the Harakat as an apolitical party, a sort

\footnotetext{
${ }^{17}$ Mawlawi and alim (plural: ulama) are used interchangeably in Afghanistan to connote learned Islamic scholars, the former term often being used as a suffix to a name (as for Mawlawi Haqqani).

${ }^{18}$ The informants who knew Qari Baba personally all agree on this point. Some informants, however, insist that he had a Pashtun father and a Hazara (hence Shia) mother, and after his funeral, there were rumors circulating that it has been a Shiite ceremony (indicating his Hazara descent).
} 
of clerical association. Decentralized (...) without political militants and without ideology' (Roy 1986: 114). Within this network, Qari Baba was a pioneer in opposing the communists with armed force. There are no signs, however, that he was engaged in any political activity prior to the 1978 communist coup. Once engaged in resistance, he quickly gained a reputation for cruelty and mercilessness. Anybody suspected of being 'a communist' - reportedly it would suffice to be a teacher, to wear pants, or to carry a mustache but no beard - would be killed, often in brutal ways. This brought Qari Baba a reputation which in many ways was an essential part of his political capital. ${ }^{19}$

Qari Baba also had a long-term, 'state-building' perspective. He held back on military offensive action. He instituted regular tax collection (usher and zakat), in part used to support his fighters, and in part to be able to offer both medical services and education to the population in areas under his command, even at an early stage in the war. ${ }^{20}$ The development of a local proto-state, where the leader could claim both tax and military services from the population, but also offered organized welfare services in return, was rather atypical among warlord commanders in the Pashtun south and southeast. In line with this, Baba acted responsibly when, already in 1988, he gained control over two major Soviet-built projects; Chardewal, an uncompleted collective farm, and Band-e- Sardeh, a large dam built for irrigation purposes. In contrast to the general pattern throughout much of the Pashtun south (Rubin 2002), Qari Baba protected the infrastructure and the equipment carefully, and handed it over to the mujahedin government when it took power in 1992. He was immediately appointed the provincial governor, and had relative success in accommodating the interests of different and mostly ethnically based political groups. Increasingly, he came to be seen as a trusted ally by leaders in the mujahedin government, and he would later be spearheading the resistance to the Taliban. In his province, he acted as a sovereign ruler, but his ability to maintain relative calm instilled respect amongst many, and Ghazni quickly became a vibrant business hub.

Qari Baba portrayed himself as an Afghan nationalist and he was extraordinarily vocal about the detrimental role played by foreign countries, particularly by Pakistan. At the same time, he cultivated relations with all sides. He worked with Pakistan, both through Harakat and directly with the Inter-Services Intelligence, ISI. He also cultivated relations with agents of the PDPA government, who were working to pacify the resistance. By 1989, when the Soviets pulled out, Baba entered into what was effectively a ceasefire agreement with the Najibullah government, who was paying him handsomely to limit his

\footnotetext{
${ }^{19}$ Hence, it was no big surprise when, in July 1993, it was reported that the armed guards of Qari Baba, the governor of Ghazni, had executed some 14 members from the Watan party (formerly known as PDPA) (Amnesty International 1993).

${ }^{20}$ The Norwegian Afghanistan Committee (NAC), a small NGO set up in solidarity with the Afghan resistance in 1980, worked closely with Qari Baba in the period 1986-1991 (Skaufjord 2006). The author was working for NAC from 1990 to 1992.
} 
military excursions. Qari Baba was critical of the radical Islamists, particularly Gulbuddin Hekmatyar's Hezb-e Islami, which not only challenged the traditional Sunni Islamic clergy, but also cultivated close relations with Pakistan and transnational political networks. Locally, in Andar, the local chapter of Hezb-e Islami was a constant challenge to his authority throughout the 1980 s and early half of the 1990 s. In one version of the events that eventually led to the Taliban takeover in late January 1995, Hezb-e Islami had launched a counterattack on the Taliban in Ghazni, but Qari Baba struck a deal with the Taliban (Dorronsoro 2005: 250). While the story about the Taliban deal remains unclear, there is no doubt that it was one of Qari Baba's second in command (and a tribal appointee) who was the main facilitator of Taliban's entry to Ghazni. His second in command had been negotiating with them for quite a while without Qari Babar's knowledge, which also led to a breakdown in the long-standing relationship between the two men.

Nonetheless, in the early months after the Taliban take-over, Qari Baba continued to serve as the governor. As Gilles Dorronsoro pointed out already in late 1994, this should not come as a surprise (Dorronsoro [1994] 2006). The objectives of the Taliban harmonized with the traditional Islamic order maintained by Qari Baba in Ghazni, and Harakat supporters in general seemed to integrate easily into the new movement. Qari Baba's relationship with the Taliban deteriorated, however, and not long after he left his governor post and sought protection with the enemy, that is, with Massoud, first in Taloqan and later in the Panshjir valley. Eventually he left for Iran where he spent almost four years, returning to Panshiir in 2001.

After 9/11, when the US started to raise an Afghan army that could confront the Taliban, Qari Baba's competence was again in demand. The change of regime once again led Qari Baba to the governor's seat in Ghazni. Realizing that Baba had a record of being brutal, but effective, Karzai reappointed him to the post as provincial governor. From the beginning, Baba was critical to the presence of international forces, and this evolved into a major disagreement with Karzai. He served as governor only until late 2002, when Karzai removed him. After this, Baba remained in Ghazni, and is widely credited for having played an active role in encouraging local warlords to cooperate in the DDR process. It therefore came as quite a surprise when, in August 2005, Qari Baba was arrested by US troops on charges of hiding arms in his home (Tarzi 2005). It was even implied that Baba had participated in the insurgency against Afghan and US forces. This seems unlikely, and has not been confirmed by any local sources. Even after this, however, Qari Baba was called upon by the government. By 2006, he served as an advisor (sometimes described as the de facto police chief) to the new governor, Sher Alam. Although his armed forces had since long been dismantled, his military competence as well as his skills as a mediator continued to be in demand in a province which was becoming increasingly conflict-ridden. 
Qari Baba was killed on 17 March 2006, alongside his son-in-law and four other men (Reuters 2006). He was returning from a visit to Ghazni city when the car was attacked by gunmen close to his house. Later on the same day, there was a failed attempt on the life of the governor as well. Spokesmen of the Taliban claimed responsibility for both attacks. While few observers dispute the involvement of the Taliban, there are several versions of the story. Some believe this was the execution of a central Taliban decision, as part of a larger campaign where religious leaders and others with local legitimacy and an agenda reminiscent of their own were eliminated (Sinno 2008: 241). Others think Qari Baba's former enemies, now part of the Taliban, had taken the initiative. These sources mention both opponents from his own mujahedin and contending groups in the same area, as well as the descendents of the 'communists' whom he so mercilessly took on in earlier days. ${ }^{21}$

The reputation of Qari Baba as a merciless warlord was well deserved. He used to build political capital, linking it - almost like the Taliban in its early days - to an ability to maintain security and order. At the same time, however, Baba hesitated to become overly reliant on external sources for money and resources, and always sought to supplement external resources with local ones. As a result, he was eager to provide the local population with education and health services as well as security. His level of local control made it attractive for successive regimes to retain him as governor, but both the Taliban and the Karzai government removed him after a brief interim period, probably fearing that a local ruler with such legitimacy could become overly independent. In the various theories as to why Qari Baba was killed there is a common element of revenge for his harsh use of violence in the past. As a compromise candidate between several tribal groups, moreover, he lacked the ultimate protection of a primary solidary group. This, as well as his reluctance to build solid ties to any external supporter, rendered him vulnerable.

\section{Jalaluddin Haqqani: Tribal-Ideological Warlord}

One of Afghanistan's most effective resistance commanders throughout the 1980s, Jalaluddin Haqqani held posts in the mujahedin government before he joined the Taliban in 1995. His primary base is within the Zadran tribe. Haqqani was a graduate of the Darul-Uloom Haqqania madrasa in Pakistan, and a trained Islamic scholar. Despite attempts to bring him over to the government's side in 2001, he has remained with the Taliban, but with a considerable degree of independence. A favorite of the US in the 1980s, Haqqani was always closely connected both to radical Islamistic forces both in

\footnotetext{
${ }^{21}$ These theories, of course, are not necessarily mutually exclusive.
} 
Pakistan and in the Gulf, and had long-standing relationships with Al-Qaeda leaders, whom he also helped set up training camps in Afghanistan. Haqqani, and increasingly his son, Sirajuddin, have played an active role in the Taliban insurgency in Pakistan's Waziristan districts as well and may most appropriately be described as a transnational warlord. Haqqani has never focused on civilian affairs, but rather on military action. In recent years, he has also been identified as a core promoter of terrorist tactics, particularly suicide bombers. ${ }^{22}$

Born in Saraneh village in Paktia in 1930, Jalaluddin Haqqani pursued religious studies, first locally and later at the famous Darul-Uloom Haqqania madrasa at Akhora Khattak in Pakistan, from where he also adopted his name. The Haqqania madrasa has for long been the main Deobandi teaching centre in Pakistan. Several central Taliban leaders have had their training there, as well as some of the key mujahedin figures of the $1980 \mathrm{~s}^{23}$ After completing his studies Jalaluddin took up teaching at the madrasa, and he developed close relations with both Mawlawi Fazlur Rehman and Qazi Hussain Ahmad, who went on to lead Pakistan's two most important Islamist parties, the Jamiat Ulema-e Islam and the Jamiat Islami respectively. Mawlawi Haqqani has two wives, one of whom is of Arab origin. ${ }^{24}$ While the family background of the second wife is unclear, it seems likely that his second marriage was used to cement political relationships to some of his radical contacts in the Gulf. Haqqani is reported to have eleven sons, of which Sirajuddin and Khalil have followed in their father's footsteps. By 2007, Sirajuddin is increasingly the one in charge of day-to-day affairs, on both sides of the border.

In general, politics in the part of Afghanistan which Haqqani hails from, the provinces of Paktia, Paktika and Khost in particular, is closely linked to tribal structures and tribal values (Glatzer 2002). Here, the traditional consensus-oriented jirga is commonly used to resolve conflict both within and between various tribes. The arbaki, a tribal force set up to maintain security in the event that jirga deliberations are unsuccessful, is widespread. ${ }^{25}$ In this environment, Jalaluddin Haqqani stands out from the crowd of warlords, deriving legitimacy more from his religious status rather than from his tribal background (Dorronsoro 2005: 114). Yet as Olivier Roy pointed out in the mid-1980s, Haqqani's front was 'very tribal in character' (Roy 1986: 128). His immediate support base was within the

\footnotetext{
${ }^{22}$ For a comprehensive and thoroughly documented account of the Haqqani front, see Ruttig (2009).

${ }^{23}$ Both Maulawi Mohammad Nabi, leader of the Harakat-e Enqilab, and Maulawi Younos Khales, leader of his own faction of Hezb-e Islami (also Jalaluddin's party in the 1980s), were graduates of the Haqqaniya madrasa.

${ }^{24}$ It if frequently claimed that his second wife is from bin Laden's family (at times, that she is his sister), but this has been difficult to verify.

${ }^{25}$ In Paktia, for example, it is claimed that there by 2006-07, there are arbaki in all districts (Schetter, Glassner and Karokhail 2007)
} 
large Zadran tribe, but not at any stage was he close to being its undisputed leader. ${ }^{26}$ Haqqani had considerable success in building support within several of the neighboring tribes as well - Mangal, Tani, and Waziri - whose territory span the Pak-Afghan border. As an Islamist, Haqqani represented a new breed of leaders in the Pashtun tribal heartlands, yet, unlike many of the other Islamist commanders, he has always had a good sense of tribal politics.

While Jalaluddin Haqqani was in close contact with several leading Islamists, certainly on the Pakistani side, it does not seem that he was politically active prior to the 1978 coup. ${ }^{27}$ By 1979, however, Haqqani is firmly with Younos Khales, who has just broken out of Hekmatyar's Hezb-e Islami and established his own party under the same name. Khales, like Haqqani, was a blend of Islamist and traditionalist-tribal, and recruited through both types of networks. Haqqani remained a member of the Hezb (Khales) until joining the Taliban in 1995, but operated virtually as an independent commander. A fluent Arabic speaker with good contacts in the Gulf, Haqqani got money from a number of wealthy supporters, and he hosted many international Islamic warriors in his bases on both sides of the border. Already by the mid-1980s, he was reputed to have very good contacts with the Inter-Services Intelligence (ISI) and the Central Intelligence Agency (CIA), and was a favorite recipient of international military aid throughout the anti-Soviet war. He was one out of ten commanders who received direct support from CIA (so-called 'unilaterals') (Rubin 2008). All in all, Haqqani's variety of contacts, both in Pakistan and internationally, by far outweighed that of his party leader, Khales, More importantly, not being dependent on any single actor gave him considerable room to maneuver. ${ }^{28}$ The case of Haqqani disproves Sinno's claim (2008: 14) that foreign sponsors tend to claim exclusivity, leaving warlord clients highly vulnerable to political shifts. With a massive reputation as an effective fighter, sponsors wanted Haqqani as a recipient, and through combining income from multiple sources, Haqqani shielded himself effectively against contextual shifts.

\footnotetext{
${ }^{26}$ His main rival in the immediate post-2001 context was Padshah Khan Zadran, who headed a local militia, based on tribal recruitment (amongst the Zadran), and on the US payroll. Padshah Khan fell out of favor with the US after openly defying the government, even through armed attack (Bhatia and Sedra 2008: 176-177; Schetter, Glassner and Karokhail 2007).

27 There are reports that he spoke out for holy war against then President Daud at Friday prayers in Khost in the mid-1970s, but this does not necessarily imply that he was an active member of any political group. Other leading Afghan Islamicists, including Gulbuddin Hekmatyar, Ahmad Shah Massoud and Burhanuddin Rabbani, were all in exile in Pakistan at the time, from where they actively worked against Daud's regime.

${ }^{28}$ Some informants would describe Haqqani as loyal to parts of the ISI, some would even claim he held a high rank within the organization. Also Peter Tomsen, former ambassador to Pakistan (1989-1992), makes this point: 'He would come to Islamabad for meetings (...) Together they would discuss the ISI plan for the next couple months, which Haqqani would then be implementing. He would not be devising strategies on his own.' (2006)
} 
Unlike Qari Baba, Haqqani was never a builder of quasi-state services for the local population. His focus was always on the armed struggle and on mobilizing the resources required to maintain the resistance. ${ }^{29}$ Most of his resources came from external sources, both in Pakistan and internationally. His fund-raising trips, as well as his son's trips to Saudi Arabia and the gulf countries, have been a good source of income. He also made considerable profit from various shady businesses, including drug smuggling, arms trading and timber export. Hence, Haqqani never needed to be accountable to the population within his territory

In March 1991, the city of Khost fell to an alliance of mujahedin, the first provincial capital to be lost by the communists. The alliance, which was led by Haqqani, quickly disintegrated, in part because Hekmatyar's group, which had played a minor role in the battle, tried to take a disproportionate part of both the credit and the control (Rubin 2002: 255). In any case, the end result was that Khost city was systematically looted by the various mujahedin groups, with a heavy impact on the civilian population. Being the first city to be captured by the mujahedin, the looting of Khost sent a loud signal about the mujahedin's disregard for civilian lives and infrastructure.

Haqqani's relationships to key personalities in Al Qaeda, including Osama bin Laden, goes back to the first half of the 1980s, when he was hosting groups of international Islamist warriors based in Pakistan's Miram Shah and the Khost region of Afghanistan. By the mid-1980s, Haqqani was already a close associate of bin Laden, and his then mentor, the late Abdullah Azzam. At the time Haqqani had his own advance base with underground facilities at Zhawar, just across the border from Pakistan. The Zhawar base had been a key logistical stronghold for the mujahedin in the 1980s. Bases in the Zhawar were also used by the international Islamists which in 1988 took the name Al Qaeda. The Zhawar base was the target of numerous attacks by PDPA and Soviet forces (Grau and Jalali 2001), and, a decade later, for the Clinton administration's missile attacks after the bombings of the US embassies in Dar-es Salam and Nairobi, when it served as a main base for Al Qaida (Wright 2007: 283). ${ }^{30}$

Khost and the surrounding Paktika province fell to the Taliban in early 1995. For the Taliban, dominated by Kandahari clerics, the early inclusion of Haqqani was important to build credibility in the eastern areas (Sinno 2008). Haqqani made a deal with the Taliban, contributing a sizeable force to its campaign which continued eastwards and ended with

\footnotetext{
${ }^{29}$ Mohammad Yousaf, chief of the Afghan Bureau of the Pakistani Inter-Services Intelligence (ISI), gives an interesting illustration of Haqqani's problems of maintaining discipline, both within his own ranks and with other fronts in the attempt to take Khost in 1986. Planning a major attack, Haqqani insisted, despite Yousaf threatening to withhold the support of his advisors, to attack in daylight, arguing that nighttime attack 'nobody would cooperate and everybody would blame each other for failure.'(Yousaf and Adkin 1992: 162)

${ }^{30}$ The other was against a pharmaceutical production plant in Sudan.
} 
the takeover of Kabul in September 1996 (Rasanayagam 2003: 149). Haqqani was ideal for Taliban co-optation:

The Taliban also astutely used their knowledge of the Pushtun landscape to decide whether to coopt, discard, or assasinate different commanders. The Taliban co-opted leaders who wouldn't tarnish their finely calibrated image as heralds of a better order and who could enhance their military potential. Jalaludin Haqqani, the master guerrilla leader and uncompromising learned scholar without independent ambitions, was the epitome of the co-optable commander. (Bhatia and Sedra 2008: 241)

Just as in the early days of the mujahedin government some three and a half years earlier, Haqqani was appointed a minister, this time for Borders and Tribal Affairs. Haqqani was only moderately engaged in his ministerial duties, which he left largely to his brother Khalil. Jalaluddin himself was now heavily engaged in the war against the Northern Alliance. He played a central role in the brutal entrenched warfare on the Shamali plains to the North of Kabul, demolishing virtually all infrastructure, and driving out most of the local population. The Shamali warfare, at its most intense in 1996-1997, has often been referred to as 'ethnic cleansing' of the majority Tajik population (Human Rights Watch 2007). Again, Haqqani's talents for warfare were put to use. As at earlier crossroads, Haqqani shied away from political and administrative duties, privileging armed action.

In the run up to the intervention in 2001, US and Pakistani intelligence jointly decided to try to convince Haqqani to support the new order. Several meetings took place in Islamabad and Rawalpindi, with little result. It has been speculated that some of Haqqani's longstanding ISI contacts encouraged him to keep up the fight, given their mixed sympathy with the US-led intervention (Gannon 2005: 269; Rashid 2008). The negotiations took place while Haqqani was hosting a number of Al Qaeda leaders. One of Haqqani's guests, according to Ahmed Rashid, was Osama bin Laden himself, in one of his safe houses in Pakistan's North Waziristan, close to the Afghan border (Rashid 2008: 99). The New York Times reporter Kathy Gannon believes Haqqani could have handed over the whole network, had he wanted to. In December 2001, at the time of Karzai's inauguration, Haqqani declared that the time to fight was over, and sent a delegation of Zadrani tribesmen to Kabul to attend. The convoy was bombed by the US, probably misinformed by one of his rivals, and some 60 people were reportedly killed (Rubin 2008). While it is hard to say how sincere Haqqani was in reconciling at this point, there is little doubt that the US bombing effectively blocked it. Over the next couple of years, Haqqani held a low profile, knowing that he was a prime target. Yet, he and his sons were deeply involved in much of the unrest that took place on both sides of the border. He appears to have been able to rebuild his armed capacity as well as his financial sources, although a significant part of his former infrastructure had either been bombed or closed down. Haqqani increasingly recruited among the Pashtuns on the Pakistani 
side of the border, who were handsomely paid to protect the foreign guests, over time forming the backbone of the so-called 'Pakistani Taliban'. With his ability to lead, or at least inspire, violence on both sides of the border, Haqqani had become a genuine transnational warlord.

The increasing adaptation of terrorist tactique in Afghanistan - the use of suicide bombers, hostage-taking, beheadings - is often said to be Haqqani's work (Giustozzi 2007: 91-92). Sirajuddin Haqqani, his son, is talked about as a representative of a new generation of Taliban, far more militant than Jalaluddin's generation (Burke 2007). ${ }^{31}$ Haqqani is a member of the inner leadership council of the Taliban. Until 2006, it seems unlikely that Haqqani played a key role in the military strategizing of the Taliban. The socalled Haqqani front was often perceived as an entity of its own, only loosely connected to the Taliban. ${ }^{32}$ After the death of Mullah Dadullah in 2006, however, there were a number of reports that Haqqani was appointed the general commander of the Taliban, probably planted to enhance his standing (Ruttig 2009: 61). The Afghan government, backed by US sources, has accused Haqqani for the attacks on Kabul's Hotel Serena in January and on the Indian embassy in July 2008 (Mazzetti and Schmitt 2008).

In sum, since the end of the 1970s, Haqqani has been known as an effective and merciless warrior. In waging warfare against the PDPA and its Soviet supporters, his long-term perspective and his use of advanced technology made him considerably more sophisticated than many contemporary warlords. The combination of a will to exert massive violence and his strategic and tactical skills made him quite an asset for the Taliban regime, particularly in its ongoing battles with the Northern Alliance from 1996 onwards. Haqqani is an archetypical warlord, initially reliant on local support, but expanding beyond the limitations set by local checks and balances. His interest in local welfare has been negligible. While expressing some good will, he ended up rejecting invitations to become part of the post-2001 regime, remaining loyal to his long-term associates within Al Qaeda and in Pakistan. Since then, he has been a key actor in Taliban's expanding repertoire of violence. He and his sons have been instrumental in transnationalizing the Taliban, in moving it from an Afghan entity with support networks and recruitment ground in Pakistan, to being a network that fights the governments of both states. In this sense, Haqqani is the archetypical transnational warlord. Initiating an advanced repertoire of violence on the Afghan war scene, he then diffused it to neighboring Pakistan. Remaining close to his one-time teachers and

\footnotetext{
${ }^{31}$ On 7 November 2007, Voice of America reported that the US led coalition offered a reward of 200,000 dollars for information that would lead to Sirajuddin's capture (2007). Jalaluddin, however, has been on the UN Security Councils 'List of Individuals and Entities Subject to Sanctions' since early 2001.

32 Reports based on US intelligence, for example, often talked about three independent elements in the insurgency, the Taliban, Hezb-e Islami (Hekmatyar) and the Haqqani network (see for example Cordesman 2006; Bowman and Dale 2009)
} 
colleagues at the Akhora Khattak madrasa, he has himself been a key agent in the radicalization of traditional religious networks on both sides of the border.

\section{Comparing the Trajectories of Afghan Warlords}

The political biographies examined above suggest that military capability and reputation remain the core of a warlord's status also when the war ends. All three men - Rocketi, Baba, Haqqani - were known as effective military commanders. They were able to economize resources and not engage in fighting when no gains were to be made; they were also capable of using extensive violence against anybody seen to threaten their rule. It is commonly assumed that the status of warlords, in order to be upheld, hinges on regular involvement in military action. However, both Baba (after deserting the Taliban in the 1990s) and Rocketi (after joining the post-2001 government) continued to be respected - even feared - years after they had engaged in military action and even long after their military infrastructure had been dismantled. A violent reputation can be an effective means of gaining respect and obedience in wartime; in politics, however, it may prove counterproductive. Indeed, Rocketi, the only one who pursued a political career, has gone to considerable lengths to distance himself from his violent past. He has had only limited success, in part because his political talent does not match his military one. Baba, balancing his military reputation with an interest in local welfare, might have been more successful had he been given the opportunity. Haqqani, with a reputation for being both merciless to his opponents and strongly against non-Pashtuns already in the 1980s, decided not to give politics a chance, perhaps realizing the insurmountable legitimacy problems he would face.

In terms of a relational mode of explanation for warlordism, we see that all three men initially relied on local support, and would never have made their mark as warlords had they not been able to continue to muster the support of local tribal networks. All three had some sort of religious stature, as was common throughout the Pashtun southeast, although less so in the cases of Rocketi and Baba. While religious position carries an element of legitimacy, the key was tribal support. At this point, the patterns differ widely. Rocketi had support from one of the less significant tribes in the area (albeit significant across the larger south and southeast), but gained wider local support because of his military skills. Baba was elected as a compromise candidate from the four major local entities, himself being an outsider, but he was encumbered by a system of subcommanders from the respective tribes who held him accountable. Hence, Baba's experience contradicts the notion, formulated at the outset, that warlords over time become increasingly sovereign by freeing themselves from local checks and balances. Haqqani conforms to the notion however: his initial basis of power was within a dominant local tribe, but accountability to local constituencies declined as his external 
financing increased. He also increasingly recruited beyond the Zadran tribe on both sides of the Pak-Afghan border. It is possible that in adapting to post-conflict politics, the warlords like Rocketi and Haqqani - would face much larger problems in that they had moved beyond the ties to their original constituency, whereas the one who was kept partially accountable - Qari Baba - would be better placed to play a genuine political role. The problem in Qari Baba's case is that the very reason he was held accountable was that he did not himself emerge from any of the tribal entities that backed him during the war, which in turn made also him vulnerable.

Applying a political economy perspective, the first point to note is that none of the three warlords were driven by economic concerns. Rather, economic resources were only a means to an end. Apart from that, there are interesting differences. The politically most vulnerable candidate, Baba, invested most heavily in local welfare. He actively sought to develop local health and education systems in areas under his control, and used this to justify both taxation and conscription amongst his subjects. Neither Rocketi nor Haqqani attempted to expand popular support through a social contract of welfare provision. Haqqani conformed more to the standard image, relying in part on income from a grey economy, but overwhelmingly on external support. In Haqqani's case, however, this does not seem to have instilled the vulnerability to external controls suggested by many analysts. Rather, being in demand for his skills at waging war, he was able to maintain support from different sources. Importantly, however, Haqqani's relative success in this regard relied on his ability to operate with considerable freedom on both sides of the Pak-Afghan border. More important, the comparison of the three men indicate that warlords who rely on local support for financing are less likely to engage in oppositional violence when the war ends. Yet, as with Rocketi, such warlords may find it difficult to maintain political influence - which also takes political skill that many warlords are lacking. In the absence of external support, warlords have to be responsive to the financial promises of a new government, as was the case with both Baba and Rocketi when the mujahedin took power in 1992.

Ideologically, there are also large differences among the three. Haqqani is so ideologically committed that he challenges a conventional concept of the warlord as a non-ideological leader, yet there is little indication that he at any stage has taken a lead in formulating general political strategies or objectives. His strength lies in providing and developing the means needed to reach radical ends. Baba, while not holding a vision for the state and the polity, was committed to local security and welfare, possibly for reasons that went beyond narrow self-interest. In terms of the model of the non-ideological warlord, Rocketi is the ideal type, not committed to a radical cause, but preoccupied with local security, and, of course, his own power. Historically, all three men owed their emergence as warlords to a degree of religious legitimacy. While their religious leadership roles as such had little impact on their conduct as warlords, they carried networks and influences that were 
decisive for later choices. Thus, Haqqani stayed committed to contacts from his madrasa days in Pakistan, whereas Rocketi was persuaded by a member of one of Afghanistan's most influential sufi families to join the Karzai government. Hence, while warlords may not be the chief ideologues, ideology - at least in its religious form - still matters. It defines the lines of commonality and differences on which solidarity and work relationships are based. Such relationships interact with the role of economic foundations and ideological orientations to define the military capacity of any warlord. Ultimately, military capacity itself is an uncertain foundation for power; it is at the interface between the three other types of factors that we can understand its robustness.

Where does this leave us when it comes to accommodation of warlords with a new political order? In his influential work, Stedman (1997; 2002) suggested three principal ways of accommodating potential 'spoilers': through coercion (the use of armed force, or the threat of using it), inducement (offering political positions or other alternatives) or socialization (the process of building a common normative foundation) (see Suhrke, Harpviken and Strand 2002). A fourth way, as the above analysis shows, would be to attack the relational base of a warlord by rebuilding structures of accountability and possibly by supporting aggrieved groups that may overturn warlords who have lost touch with their erstwhile supporters (see e.g. Marten 2007). These four strategies for dealing with warlords correspond to the broad framework informing this article: military skill (i.e. coercion), political economy (i.e. inducement), ideology (i.e. socialization), and relations (i.e. accountability). The four are not necessarily mutually exclusive. In the case of Rocketi, for example, all seem to have been at work: the threat of coercion was instrumental in convincing him to lay down arms, the promise of a political future solidified the decision, and his responsiveness to local supporters (and political mentors) did likewise insofar as his participation in the political process was meant to convince them he would not to revert to violent means. With Haqqani, this combined strategy did not work. He was largely unresponsive to a local constituency, he had generous access to external support that made an alternative course of action possible, he was deeply embedded with individuals and organizations committed to the insurgency, and, when he explored accommodation by sending a delegation to Kabul to attend Karzai's inauguration, the international coercive apparatus (probably being intentionally misled) responded by killing 60 of his men and thus effectively sealed off the path of co-option. 


\section{Bibliography}

2006. "Jalaluddin Haqqani." Frontline.

2007. "Reward for Afghan Terror Leader." New York: Voice of America News.

Abdullaev, Kamoludin N. (2004) Beyond Reconstruction in Afghanistan: Lessons from

Development Experience, New York: Palgrave Macmillan.

Amnesty International (1993) Afghanistan: Political Crisis and the Refugees, London:

Amnesty International.

Berdal, Mats (2003) 'How "New" are the "New Wars": Global Economic Change and the Study of Civil War', Global Governance, 9: 477-502.

Bhatia, Michael, and Sedra, Mark (2008) Afghanistan, Arms and Conflict: Armed Groups,

Disarmament and Security in a Post-War Society, London: Routledge.

Bowman, Steve and Dale, Catherine (2009). 'War in Afghanistan: Strategy, Military

Operations, and Issues for Congress', CRS Report for Congress, Washington DC:

Congressional Research Service

Burke, Jason (2007) 'The New Taliban', The Observer, 14 October.

Collier, Paul, and Hoeffler, Anke (2002). Greed and Grievance in Civil War, Oxford: Centre for the Study of African Economics.

Cordesman, Anthony H. (2006) 'One War We Can Still Win', New York Times, 13

December.

Dorronsoro, Gilles (2005) Revolution Unending: Afghanistan, 1979 to the Present, New

York: Columbia University Press.

_ ([1994] 2006) 'Le Mouvement des Taleban en Afghanistan', Cemoti, 19.

Earle, Timothy (1997) How Chiefs Come to Power: The Political Economy in Prehistory,

Stanford, CA: Stanford University Press.

Edwards, David Busby (1986) 'Charismatic Leadership and Political Process in

Afghanistan', Central Asian Survey, 5: 273-299.

Gannon, Kathy (2005) I is for Infidel: From Holy War to Holy Terror, New York: Public Affairs.

Giustozzi, Antonio (2003) Respectable Warlords? The Politics of State-Building in Post-

Taleban Afghanistan, Crisis States Programme Working papers series 1, 33,

London: Crisis States Research Centre, London School of Economics and Political

Science.

_ (2004) "Good" State vs. "Bad" Warlords? A Critique of State-Building Strategies in

Afghanistan, Crisis States Programme Working papers series 1, 51, London: Crisis

States Research Centre, London School of Economics and Political Science.

— (2005) The Debate on Warlordism: The Importance of Military Legitimacy, Crisis States

Discussion Papers, 13, London: Crisis States Research Centre, London School of

Economics and Political Science.

- (2007) Armed Politics and Political Competition in Afghanistan, CMI Working Paper,

Bergen: Chr. Michelsen Institute. 
Glatzer, Bernt (2002) 'The Pashtun Tribal System', in Georg Pfeffer and Deepak Kumar Behera (eds) Concept of Tribal Society, New Delhi: Concept Publishers, pp. 265282.

Grau, Lester W., and Jalali, Ali Ahmad (2001) 'The Campaign for the Caves: The Battles for Zhawar in the Soviet-Afghan War', The Journal of Slavic Military Studies, 14(3): 69-92.

Harpviken, Kristian Berg (1997) 'Transcending Traditionalism: The Emergence of NonState Military Formations in Afghanistan', Journal of Peace Research, 34: 271-287. — (2003) 'Afghanistan: From Buffer State to Battleground - to Bridge between Regions?' in James J. Hentz and Morten Bøås (eds) Beyond the Nation State: New and Critical Security and Regionalism, Aldershot: Ashgate, pp. 152-176.

Human Rights Watch (2007) The Human Cost: The Consequences of Insurgent Attacks in Afghanistan, New York: Human Rights Watch.

Keen, David (1998) The Economic Functions of Violence in Civil Wars, Adelphi Paper 320, London: International Institute of Strategic Studies.

Kibel, Amanda (2001) "Live from Afghanistan." CNN. 18 December.

Marten, Kimberly (2007) 'Warlordism in Comparative Perspective', International Security, 31: 41-73.

Mazzetti, Mark, and Schmitt, Eric (2008) 'Pakistanis Aided Attack in Kabul, U.S. Officials Say', New York Times, 1 August.

Menkhaus, Ken (1998) 'Somalia: Political Order in a Stateless Society', Current History, 97(619): 220-224.

- (2004) Somalia: State Collapse and the Threat of Terrorism, Adelphi Paper 364, London: International Institute for Strategic Studies.

Miliband, David (2008) 'British troops have a clear mission in Afghanistan', Telegraph, 21 June.

Olson, Mancur (1993) 'Dictatorship, Democracy and Development', American Political Science Review, 87(3): 567-576.

Rahmani, Waliullah (2008) 'Jalaluddin Haqqani Challenges Mullah Omar's Leadership of the Taliban', Terrorism Focus, 5(25): 3-4.

Rasanayagam, Angelo (2003) Afghanistan: A Modern History, London: I.B. Tauris.

Rashid, Ahmed (2000) Taliban: Islam, Oil and the New Great Game in Central Asia, London: I B Tauris.

- (2008) Descent into Chaos: How the War against Islamic Extremism is being Lost in Pakistan, Afghanistan and Central Asia, London: Allen Lane.

Reno, William (1998) Warlord Politics and African States, Boulder, CO: Lynne Rienner. _ (2002) 'Mafiya Troubles, Warlord Crisis', in Mark R. Beissinger and Crawford Young (eds) Beyond State Crisis? Postcolonial Africa and Post-Soviet Eurasia in Comparative Perspective, Baltimore, MD: Johns Hopkins University Press, pp. 105127.

Reuters (2006) 'Taliban Kill Ex-Official and Guards', New York Times, 19 March. 
Roy, Olivier (1986) Islam and Resistance in Afghanistan, Cambridge: Cambridge University Press.

Rubin, Barnett R. (2002) The Fragmentation of Afghanistan: State Formation and Collapse in the International System, 2nd edn, New Haven: Yale University Press.

- (2003) 'Identifying Options and Entry Points for Disarmament, Demobilization and Reintegration in Afghanistan', Center on International Cooperation, New York University.

_ (2008) 'New York Times on ISI: Serence Hote Attack (Plus Update Connecting the Two and Historical Background)'. Online blog post. Available HTTP:

http://icga.blogspot.com/2008/01/new-york-times-on-isi-serena-hotel.html.

Ruttig, Thomas (2009) 'Loya Paktia's Insurgency: The Haqqani Network as an

Autonomous Entity', in Antonio Giustozzi (ed.) Decoding the New Taliban: Insights from the Afghan Field, New York: Columbia University Press, pp. 57-88.

Sands, Chris (2006) 'Afghan MPs Predict “Very Big War”', The Dominion, 19 December. Available HTTP:

http://www.dominionpaper.ca/accounts/2006/12/19/afghan_mps.html.

Schetter, Conrad; Glassner, Rainer, and Karokhail, Masood (2007) 'Beyond Warlordism:

The Local Security Architecure in Afghanistan', Internationale Politik und

Gesellschaft, 2: 136-153.

Sennott, Charles (2007) 'Afghanistan at the Tipping Point', Carnegie Reporter, 4(3): 2-11. Shahrani, M. Nazif (1984) 'Introduction: Marxist “Revolution” and Islamic Resistance in Afghanistan', in M.N. Shahrani and R.L. Canfield (eds) Revolutions and Rebellions in Afghanistan, Berkeley: Institute of International Studies, University of California.

Sinno, Abdulkader H (2008) Organizations at War in Afghanistan and Beyond, Ithaca, NY: Cornell University Press.

Skaufjord, Terje (2006) 'Qari Baba drept av Taliban', in AfghanistanNytt, 1-2006.

Stedman, Stephen John (1997) 'Spoiler Problems in Peace Processes', International Security, 22: 5-53.

— (2002) 'Introduction', in Stephen John Stedman, Donald Rotchild, and Elizabeth M. Cousens (eds) Ending Civil Wars: The Implementation of Peace Agreements, Boulder, CO: Lynne Rienner, pp. 1-40.

Strand, Arne (2008) 'Fighting for Peace? The Role of Former Combatants and the Afghan Peace Process', in Stephen Baranyi (ed.) The Paradoxes of Peacebuilding Post-9/11, Vancouver: University of British Columbia Press, pp. 235-262.

Suhrke, Astri; Harpviken, Kristian Berg, and Strand, Arne (2002) 'After Bonn: Conflictual Peacebuilding', Third World Quarterly, 23: 875-891.

Tarzi, Shah M (2005) 'Afghanistan Report', Radio Free Europe/Radio Liberty. 18 August. Tilly, Charles (2003) 'Armed Force, Regimes and Contention in Europe since 1650', in Diane E. Davis and Anthony W. Pereira (eds) Irregular Armed Forces and their Role 
in Politics and State Formation, Cambridge: University of Cambridge Press, pp. 3781.

US Department of State (1995) 'Afghanistan Human Rights Practices: 1994’. Online. Available HTTP:

http://dosfan.lib.uic.edu/ERC/democracy/1994_hrp_report/94hrp_report_sasia/A fghanistan.html

Weinstein, Jeremy M. (2007) Inside Rebellion: The Politics of Insurgent Violence, Cambridge: Cambridge University Press.

Wilder, Andrew (2005) A House Divided? Analysing the 2005 Afghan Elections, Kabul: Afghanistan Research and Evaluation Unit.

Wood, Elisabeth Jean (2008) 'The Social Processes of Civil War: The Wartime Transformation of Social Networks', Annual Review of Political Science, 11: 539561.

Woodward, Bob (2002) Bush at War, New York: Simon \& Schuster.

Wright, Lawrence (2007) The Looming Towers: Al-Qaeda's Road to 9/11, London: Penguin. Yousaf, Mohammad, and Adkin, Mark (1992) The Bear Trap: Afghanistan's Untold Story, Lahore: Jang Publishers.

Yusufzai, Rahimullah (2002) "Still on the Run: The Hunt for Top Al-Qaeda and Taliban Leaders Continues..." in Newsline. 


\section{U nderstanding Warlordism}

Three Biographies from Southeastern Afghanistan

How do 'warlords' - defined tion and the transitional chal- where they operated and the in the Afghan context both by lenges that followed led the challenges they faced, their their military skills and capaci- three men in different direc- personal trajectories diverged ty to strike a balance between tions. Rocketi took up a politilocal and external sources of cal career, was elected to parsupport - respond when the war they are fighting ends? Why do some choose compliance with the new political order while others remain engaged in various forms of opposition? The political biographies of three longstanding warlords of the largely Pashtun southeast of Afghanistan Mullah Rocketi, Qari Baba, and Jalaluddin Haqqani - enable us to explore the dynamics of quite different responses. The 2001 US-led intervenliament in 2005, and four years later remained an active player in legal politics. Qari Baba served briefly as a governor but was dethroned to the position of a security advisor and then assassinated. Haqqani stayed with the Taliban to become one of its most central commanders and by late 2009 led one of the major militant groups in the insurgency. Notwithstanding the considerable social and political similarities in the context in the post-2001 period. This paper attempts to understand why this was so; why did one man lay down his arms to become a politician, another place his capacity for commanding violence at the service of the new Karzai government, while the third continued to challenge the new rulers with armed force? The analysis of these trajectories will providean insight into the nature of violent warlordism during the formal transition from war to peace and into the post-conflict period. 